\title{
Thermal hydraulic simulations of the Angra 2 PWR
}

\author{
Javier González-Mantecón, Antonella Lombardi Costa, Maria Auxiliadora Fortini Veloso, Claubia Pereira, Patrícia \\ Amélia de Lima Reis, Adolfo R. Hamers ${ }^{*}$, and Maria Elizabeth Scari \\ Departamento de Engenharia Nuclear, Universidade Federal de Minas Gerais Av. Antônio Carlos, 6627, Escola de Engenharia, \\ Pampulha CEP 31270-901, Belo Horizonte, Brazil
}

Received: 11 May 2015 / Received in final form: 15 July 2015 / Accepted: 17 August 2015

Published online: 05 December 2015

\begin{abstract}
Angra 2, the second Brazilian nuclear power plant, began the commercial operation in 2001. The plant is a pressurized water reactor (PWR) type with electrical output of about $1350 \mathrm{MW}$. In the present work, the thermal hydraulic RELAP5-3D code was used to develop a model of this reactor. The model was performed using geometrical and material data from the Angra 2 final safety analysis report (FSAR). Simulations of the reactor behavior during steady state and loss of coolant accident were performed. Results of temperature distribution within the core, inlet and outlet coolant temperatures, coolant mass flow, and other parameters have been compared with the reference data and demonstrated to be in good agreement with each other. This study demonstrates that the developed RELAP5-3D model is capable of reproducing the thermal hydraulic behavior of the Angra 2 PWR and it can contribute to the process of the plant safety analysis.
\end{abstract}

\section{Introduction}

As the global population increases, the demand for energy and the benefits that it provides also grow up. With the worldwide concern over global warming, it is necessary to use clean sources, which do not cause the greenhouse effect. Nuclear energy is increasingly considered an attractive energy source that can bring an answer to this increasing demand, but safety of nuclear power reactors is one of the most important public worries.

For many years, the main research area in the nuclear field has been focused on the performance of nuclear power plants (NPPs) during accident conditions. In order to simulate the behavior of water-cooled reactors, the nuclear engineering community developed several complex thermal hydraulic codes systems. RELAP5-3D [1], developed by the Idaho National Laboratory, is one of the most used best-estimate thermal hydraulic codes. It is capable of performing steady state, transient and postulated accident simulations, including loss of coolant accidents (LOCAs) and a several types of transients in light water reactors (LWRs).

The aim of this work is to simulate the Angra 2 nuclear reactor behavior during steady state condition and for a postulated Small Break Loss of Coolant Accident (SBLOCA) in the primary circuit, using the thermal hydraulic computer code RELAP5-3D [2-4]. The accident simulated consists of a total break $\left(200 \mathrm{~cm}^{2}\right)$ in the cold-leg

*e-mail: adolforhamers@gmail.com piping of one of the reactor loops. A variety of break sizes in the cold-leg and hot-leg piping and other parts of the reactor coolant system representing a typical range and locations of small- and medium-break LOCAs are described and studied in the final safety analysis report of Angra 2 [5]. Hence, that document is taken as reference for the development of the present work.

\section{Model description}

\subsection{Angra 2 plant description}

In June 1975, it was signed a cooperation agreement for the peaceful uses of nuclear energy between Brazil and the Federal Republic of Germany. Under this agreement, Brazil acquired two nuclear plants, Angra 2 and 3, from the German company Siemens/KWU, currently Areva ANP. The Almirante Âlvaro Alberto NPP - Unit 2 (Angra 2) is located on the Atlantic Coast in a bay at the western extremity of the Brazilian state of Rio de Janeiro.

The second Brazilian nuclear power plant began commercial operation in 2001. The plant is equipped with a pressurized water reactor with an electrical output of about $1350 \mathrm{MWe}$, which uses light water as both reactor coolant and moderator. The PWR is designed as a four-loop plant, which is based on the proven technology of other four-loop plants. Some technical data of the plant are shown in Table 1 [5]. 
Table 1. Some technical data of the Angra 2 NPP.

\begin{tabular}{ll}
\hline Reactor power & \\
Reactor thermal power & $3771.4 \mathrm{MW}$ \\
Gross electrical & $1350 \mathrm{MW}$ \\
Thermal yield & $35.8 \%$ \\
Reactor core & Enriched uranium - $\mathrm{UO}_{2}$ \\
Fuel material & 193 \\
Number of fuel elements & 236 \\
Number of fuel rods & Zircaloy $4(\mathrm{Zr})$ \\
per assembly & $0.72 \mathrm{~mm}$ \\
Cladding material & $20.7 \mathrm{~kW} / \mathrm{m}$ \\
Thickness & $34{ }^{\circ} \mathrm{C}$ \\
Mean linear power density & \\
Mean temperature rise & \\
in core & 4 Loops \\
Plant systems & 4 \\
Primary system description & \\
Number of pumps of the & $45.7 \mathrm{MPa}$ \\
Primary system pressure & $150.6^{\circ} \mathrm{C}$ \\
Average temperature & \\
Steam generator & Vertical U-Tubes \\
Type & $20 \mathrm{Mn} \mathrm{Mo} \mathrm{Ni} 55$ \\
Material & Incoloy 800 \\
Tubes &
\end{tabular}

\subsection{RELAP5-3D nodalization}

The structure of the RELAP5-3D nodalization is simple (Fig. 1) and it is based on the component design and operating data. The model contains 162 hydraulic components and 14 heat structures (HSs). All the four coolant loops are independently modeled. The loops were simulated symmetrically except for the differences due to the location of the pressurizer in loop 1. All loops have steam generators (SGs) that include both the primary and secondary sides with heat exchange structures.

Both the SG inlet and outlet plena are modelled as a separated branch. The SG tubes are represented by a pipe consisting of an "up" (hot) leg and a "down" (cold) leg, and each one is represented by eight volumes. The secondary side nodalization is limited to the SG riser and downcomer, the SG dome and the main steam line. Both the main feedwater system (MFW) and the emergency feedwater system (EFW) are modelled by a separate time-dependent volume (TDV) and time-dependent junction (TDJ) for each steam generator. The main steam relief valve (MSRV) is modelled by a trip valve. The four reactor coolant pumps (RCPs) included in this system are identical for each loop and contain realistic characteristics.

The coolant flow area through the core was divided into 10 regions (600-609) representing the same number of thermal hydraulic channels, and heat structures were associated to each one. The effective flow rate for heat transfer in the core is $17,672 \mathrm{~kg} / \mathrm{s}$. A non-heated channel represents the bypass (550). Thermal hydraulic channels and its connected heat structures were subdivided axially into 34 volumes. The axial power distribution was calculated considering a cosine profile. The 3D capability of RELAP5-3D code for conducting neutronic calculations was not used. In a 3D reconstruction, it is possible to define exactly the position of the fuel element in the core to perform more realistically the transient evolution [6]. The point reactor kinetics model was used to compute the transient behavior of the neutron fission power in the nuclear reactor. Appropriate factors were defined to account for the fraction of the thermal power produced in the fuel rods and the one released to the coolant. The ANS79-3 decay heat model was selected to calculate the fission product decay.

The emergency core cooling system (ECCS) is also modelled, including accumulators (146, 246, 346 and 446) and safety injection (SI) pumps. The SI pumps are represented by TDV $(142,242,342$ and 442$)$ to set-up the boundary conditions of the injected water (temperature and pressure), and a TDJ (144, 244, 344 and 444) to impose the mass flow rate. Values of geometrical dimensions, set-up points and initial conditions used are given in the reference document [5].

Control variables are included in the RELAP5-3D model to simulate the main control logic of primary system and the ECCS actuation during accident scenario.

\subsection{Accident description}

The transient analyzed is the postulated $200-\mathrm{cm}^{2}$ break in the cold-leg of loop 2. This size of break falls into the category of SBLOCA, in which the secondary side is always required for heat removal from the reactor coolant system (RCS). The accident initial and boundary conditions are described in the FSAR. The simulation of this accident was performed by incorporating the logic of operation of the reactor protection system. The conditions considered are:

- Reactor power - $100 \%$ nominal power.

- Reactor trip from RCS pressure $\left(P_{\mathrm{RCS}}\right)<13.2 \mathrm{MPa}$.

- Offsite power is not available.

- Reactor coolant pumps coast down.

- ECCS criteria, $P_{\mathrm{RCS}}<11.0 \mathrm{MPa}$ and pressurizer level $\left(L_{\mathrm{PRZ}}\right)<2.28 \mathrm{~m}$.

- Emergency feedwater supply to the SG secondary side, SG level $\left(L_{\mathrm{SG}}\right)<5 \mathrm{~m}$.

Shutdown of the reactor is performed by inserting the control rods, which is assumed to be initiated from the second trip signal $-P_{\mathrm{RCS}}<13.2 \mathrm{MPa}$ - to be issued during the course of the accident. To ensure a conservative delay time for the actuation of the SI pumps, it is assumed that offsite power is not available and that loss of offsite power occurs at the same time as reactor trip. For a conservative availability of the ECCS, it is assumed that the diesel engines of loops 3 and 4 are not available because of single failure and repair, respectively (see Tab. 2). Failure and repair criteria are adopted for the ECCS components in order to verify the system operation in carrying out its 


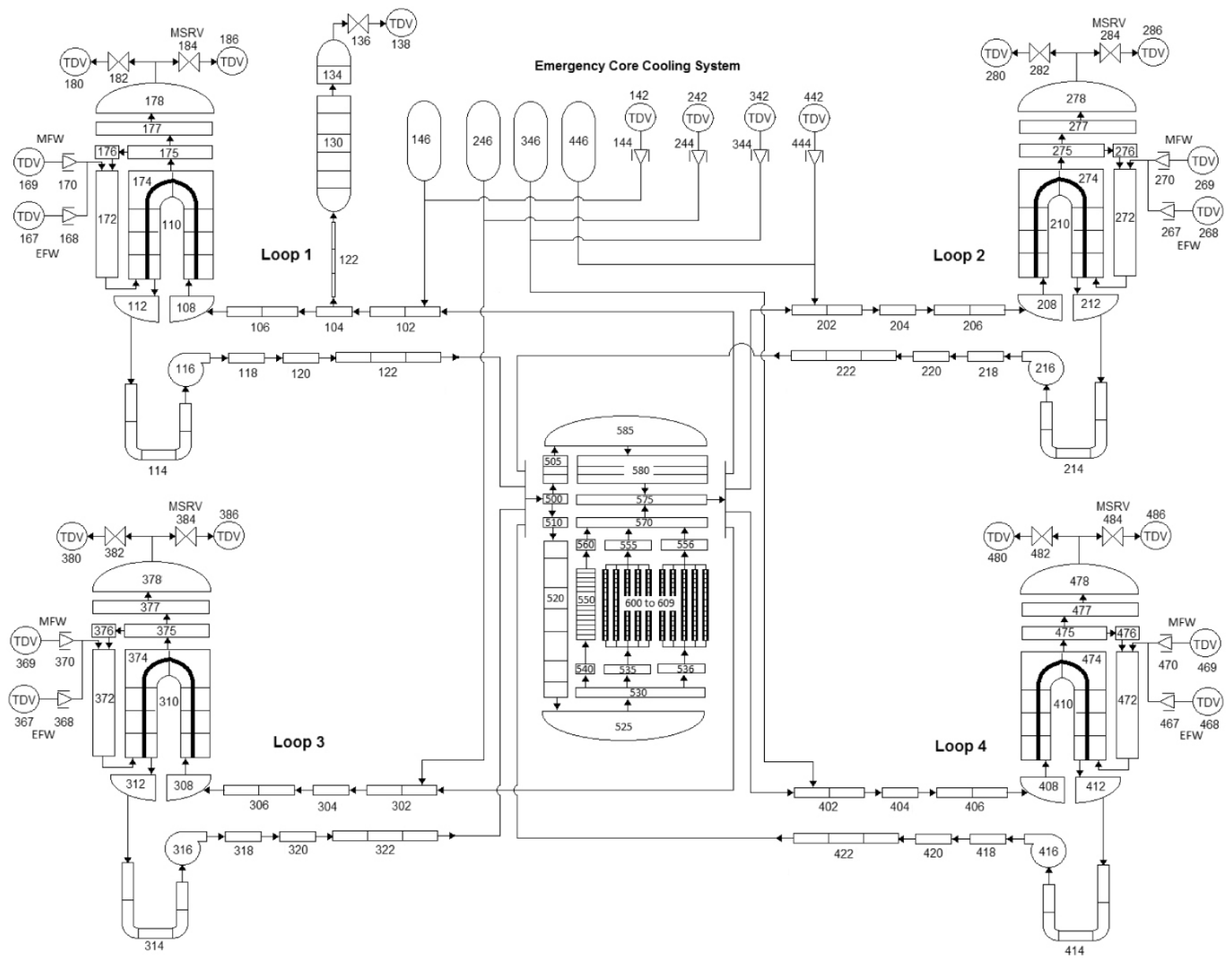

Fig. 1. RELAP5-3D nodalization for the Angra 2 PWR.

function as expected to preserve the integrity of the reactor core and to guarantee its cooling.

The reactor coolant pumps coast down due to the postulated loss of offsite power. If offsite power was available, the RCPs would be switched off by the reactor protection system when the ECC criteria are met or when the pressurizer level criteria $-L_{\mathrm{PRZ}}<2.28 \mathrm{~m}$ - is met.

When the ECC criteria $-P_{\mathrm{RCS}}<11.0 \mathrm{MPa}$ and $L_{\mathrm{PRZ}}<2.28 \mathrm{~m}-$ are met, the SI pumps are started. When the RCS pressure decrease to 2.6 MPa, the initial pressure of the accumulators, the accumulators start to inject borated water into the reactor coolant system.

Because of the assumed loss of offsite power and postulated unavailability of loops 3 and 4 diesel engines, and assuming that the startup and shutdown pumps are electrically connected to these diesel engines, the startup and shutdown pump are not available to provide water to the secondary side of the steam generators. Water is therefore supplied by the emergency feedwater pumps, which will be started when the secondary level drops below $5 \mathrm{~m}$ and injects water at $36 \mathrm{~kg} / \mathrm{s}$ per steam generator.

According to FSAR, for this transient, it must be demonstrated that the following acceptance criteria are met under best-estimate conditions:

- Cladding temperature $<1200{ }^{\circ} \mathrm{C}$.

- Local cladding oxidation $<17 \%$.

- No fuel centerline melting.

Table 2. Availability of the ECCS components [5].

\begin{tabular}{lllllllll}
\hline ECCS components & Injection & \multicolumn{1}{l}{} & & & & \\
\hline & Loop 1 & & Loop 2 & & Loop 3 & & Loop 4 \\
\hline & Hot & Cold & Hot & Cold & Hot & Cold & Hot & Cold \\
\hline Safety injection pumps & 1 & - & 1 & - & SF & - & RC & - \\
Accumulators & 1 & - & 1 & - & 1 & - & 1 & - \\
\hline
\end{tabular}

SF: single failure of diesel engine; RC: diesel engine down for repair. 
Table 3. Comparison between the steady state thermal hydraulic parameters calculated by RELAP5-3D code and FSAR data.

\begin{tabular}{llll}
\hline Parameter & Nominal value & RELAP5-3D & Error $^{*}$ \\
\hline $\begin{array}{l}\text { Reactor coolant system side } \\
\text { Reactor thermal power } \\
\text { Coolant temperature }\end{array}$ & $3771.4 \mathrm{MW}$ & $3771.4 \mathrm{MW}$ & $0.0 \%$ \\
RPV inlet & $292.1^{\circ} \mathrm{C}$ & $293.45^{\circ} \mathrm{C}$ & $0.46 \%$ \\
RPV outlet & $326.1^{\circ} \mathrm{C}$ & $328.40{ }^{\circ} \mathrm{C}$ & $0.71 \%$ \\
Coolant pressure & $16.05 \mathrm{MPa}$ & $16.19 \mathrm{MPa}$ & $0.87 \%$ \\
RPV inlet & $15.7 \mathrm{MPa}$ & $15.59 \mathrm{MPa}$ & $0.70 \%$ \\
RPV outlet & & & $0.53 \%$ \\
Coolant mass flow rates & $4700 \mathrm{~kg} / \mathrm{s}$ & $4675.28 \mathrm{~kg} / \mathrm{s}$ & $0.53 \%$ \\
Total loop flow rate & $18,800 \mathrm{~kg} / \mathrm{s}$ & $18,701.23 \mathrm{~kg} / \mathrm{s}$ & $0.64 \%$ \\
Total RPV flow rate & & & $0.25 \mathrm{MPa}$ \\
Secondary side & $6.29 \mathrm{MPa}$ & $217.85{ }^{\circ} \mathrm{C}$ & $0.85 \%$ \\
Pressure at SG exit & $218.9{ }^{\circ} \mathrm{C}$ & $2086 \mathrm{~kg} / \mathrm{s}$ & \\
Feedwater temperature & $2068.4 \mathrm{~kg} / \mathrm{s}$ &
\end{tabular}

$*$ Error $=100 \times \mid($ Nominal value - calculated value $) /$ Nominal value $\mid$.

Additionally, the core must remain amenable to cooling during and after the event. These criteria were established to provide significant margin in the emergency core cooling system performance following a LOCA.

\section{Results}

\subsection{Steady state simulation}

To verify a RELAP5 nodalization, the model must reproduce the steady state conditions of the simulated system with acceptable margins. Moreover, the nodalization must have a geometric fidelity with the system and to reproduce satisfactorily the time evolution conditions [7].

RELAP5-3D steady state calculations were performed for Angra 2 PWR operating at 3771.4 MWt. The steady state parameters calculated are presented in Table 3 and are compared with the nominal values provided in FSAR. The results show good agreement with the reference data and the calculated errors are in correspondence with the usual criteria for quantification of the steady state prediction quality that have been adopted $[8,9]$. This means that the model reproduces with good approximation the steady state thermal hydraulic behavior of the reactor.

In most reactor designs, $200 \mathrm{~s}$ null transient is typically sufficient time to achieve stable steady state conditions [5,8]. The dynamic behavior of the models is satisfactory and most of the equilibrium values were reached, or their rates of change were small after first $200 \mathrm{~s}$ of calculations.
The time evolution of the coolant temperature and pressure at inlet and outlet of the reactor pressure vessel (RPV) are shown in Figure 2. As can be seen, temperatures reach stable condition in approximately $50 \mathrm{~s}$ of simulation. It is also possible to conclude that the pressure drop in the vessel predicted by the code is approximately $0.6 \mathrm{MPa}$.

Figure 3a presents the time evolution for the heat structure 6050 (HS-605) fuel centerline temperature at four different axial levels. In addition, Figure 3b shows the fuel centerline and cladding temperature evolution for the heat structure 6050 associated to the channel 605 at mid high (level 18). As it can be observed, these temperatures are completely stables and are within the expected range [5].

As for the axial power distribution, also the axial fuel temperature distribution follows the cosine-shaped profile, reaching higher temperatures in central part of the element as shown in Figure 4 for the case of the HS-6050. As it was expected, the coolant temperature increases as the fluid movement along the heated length. The results are in agreement with theoretical predictions [10].

\subsection{Transient analysis}

The break is modelled adding a trip valve (800), which connects the reactor coolant line with the containment. The valve is opened after $300 \mathrm{~s}$ of steady state simulation, and its area is equal to the break area. On the side of the reactor coolant line, the valve is attached to the center or the respective hydraulic volume. Figure 5 gives a nodalization diagram of the break in the cold-leg of loop 2. The containment pressure is established by a time-dependent volume (802). 
(a)

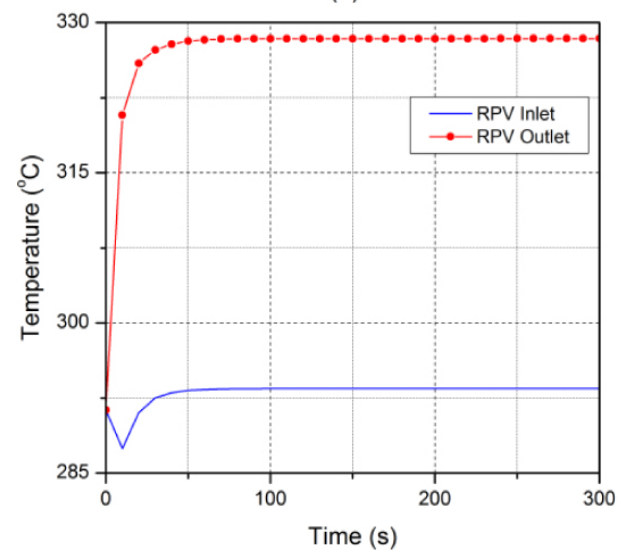

(b)

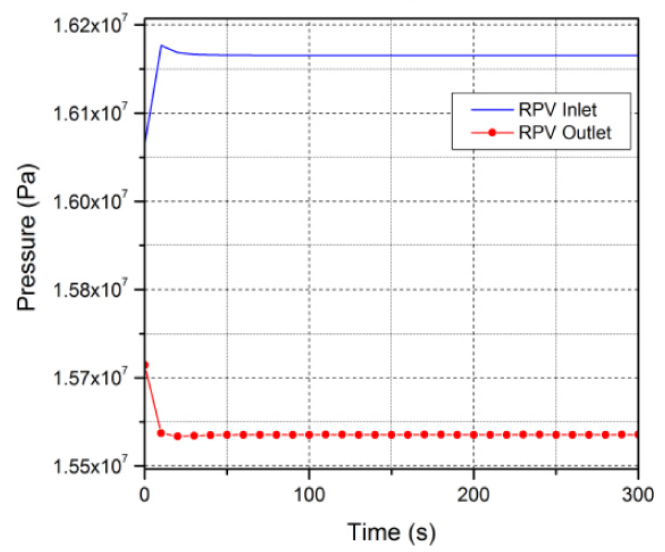

Fig. 2. Time evolution of coolant temperature (a) and pressure (b) at inlet and outlet of the RPV.

(a)

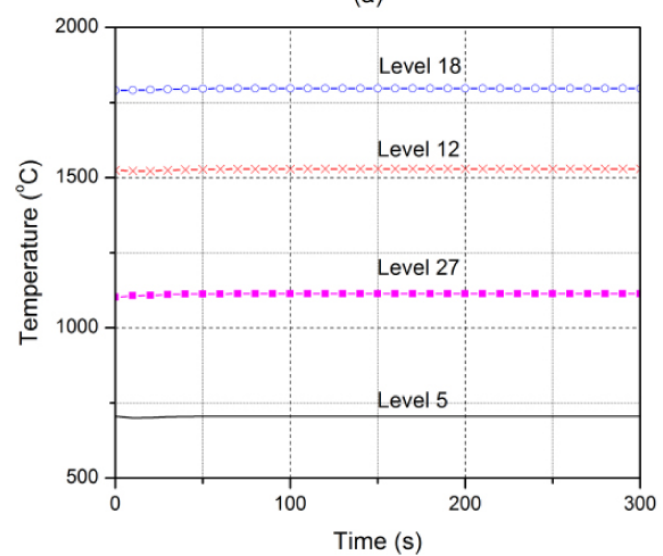

(b)

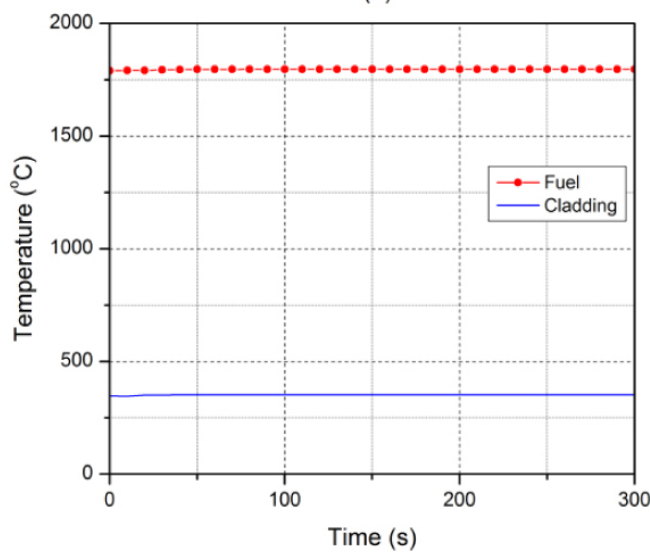

Fig. 3. Time evolution of fuel temperature at different axial positions in HS-6050 (a). Fuel and cladding temperature at level 18 (b).

(a)

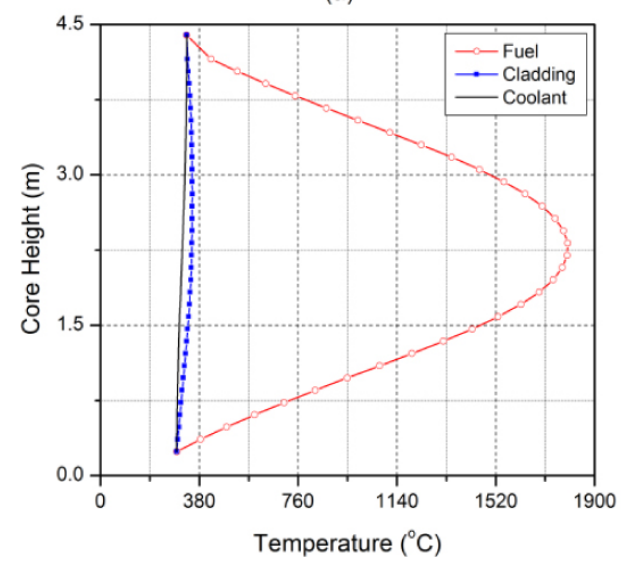

(b)

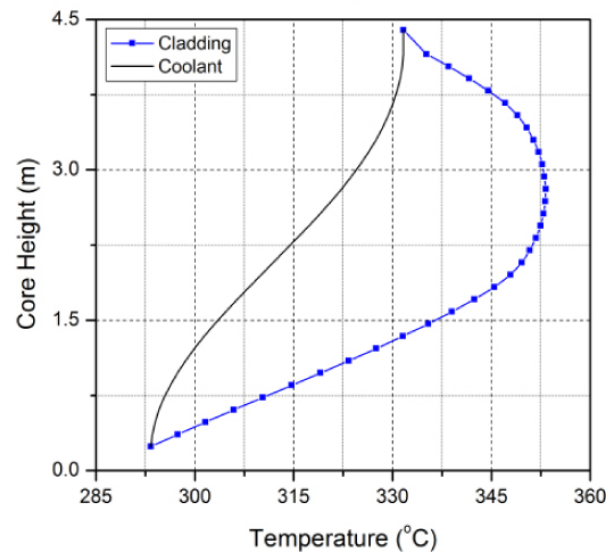

Fig. 4. Axial distribution of fuel, cladding and coolant temperatures (a). Comparison of coolant and cladding temperatures (b).

Because of the initial break flow rate and the incompressibility of the subcooled reactor coolant, the pressure on the primary side drops rapidly. At the same time, the loss of external power is assumed, which results in the RCPs coast down. The sequence of events is summarized in Table 4.
Figure 6a shows the mass flow rate through the break. The accident beginning is characterized by a sudden discharge of subcooled water into the containment. A fast depressurization of the primary system also occurs. The coolant pressure at inlet and outlet of the RPV can be seen in the same figure (Fig. 6b). 


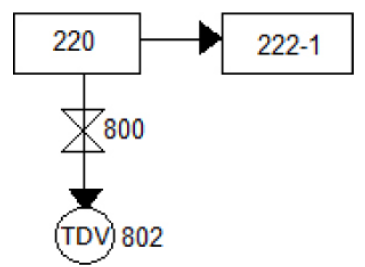

Fig. 5. RELAP5-3D nodalization diagram of the break.

Table 4. Sequence of events in the accident evolution.

\begin{tabular}{ll}
\hline Event & Time $(\mathrm{s})$ \\
\hline $1-$ Break initiation & 0 \\
$2-$ Reactor trip from RCS pressure & 16 \\
$\left(P_{\mathrm{RCS}}<13.2 \mathrm{MPa}\right)$ & \\
$3-\mathrm{ECC}$ criteria met $\left(P_{\mathrm{RCS}}<11.1 \mathrm{MPa}\right.$ & 47 \\
and $\left.L_{\mathrm{PRZ}}<2.28 \mathrm{~m}\right)$ & 47 \\
$4-$ Safety injection pumps start & 82 \\
$5-$ Accumulators injection start & 950 \\
6 - Steam generators level recovered & 1200 \\
7 - Calculation terminated & \\
\hline
\end{tabular}

At $16 \mathrm{~s}$, the RCS pressure $<13.2 \mathrm{MPa}$ and reactor protection system signal is generated. The control rods are inserted, beginning the fast reactor shutdown; $31 \mathrm{~s}$ later, the SI pumps start to deliver ECC water. The initial break mass flow rate is much higher than the injection rate of the SI pumps, then, the coolant inventory of the RCS is reduced continuously, and thus, the collapsed liquid levels in the core and the steam generator tubes gradually decrease. Because of the assumed loss of offsite power and the postulated unavailability of loops 3 and 4 diesel engines, the startup and shutdown pumps are not available to provide water to the secondary side of the SGs. Water is therefore supplied by the emergency feedwater pumps only, which are started when the secondary side water level drops below $5 \mathrm{~m}$. Steam generators level is recovered about $950 \mathrm{~s}$ after the transient beginning (see Fig. 7b). The reactor total power evolution during the transient is represented in Figure 7a.

Approximately $1000 \mathrm{~s}$ after transient started, the volume of liquid injected by the ECCS is sufficient to compensate the loss of coolant through the break, as can be observed in Figure 8a. At the beginning of the transient, the cladding temperature starts to rise, reaching a peak of $752.34{ }^{\circ} \mathrm{C}$ at $18 \mathrm{~s}$. With the quick actuation of control and

(b)

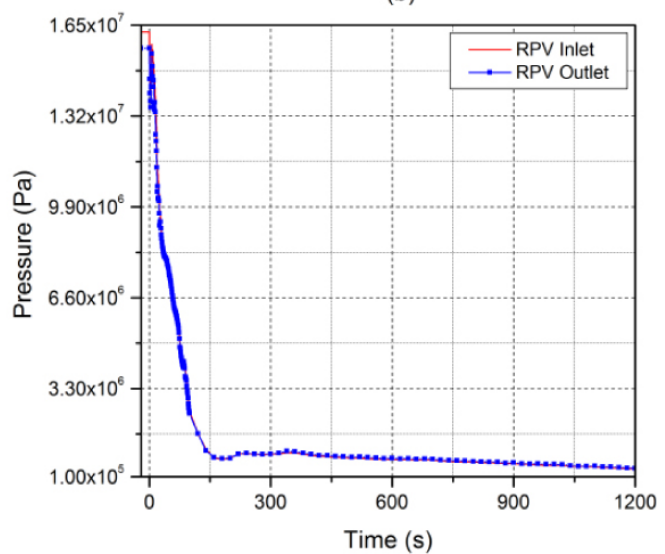

Fig. 6. Total break mass flow rate (a). Coolant pressure at inlet and outlet of the RPV (b).

(a)

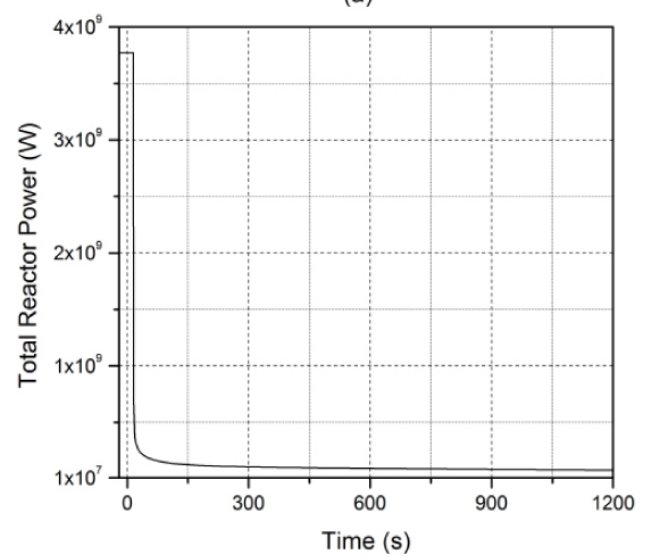

(b)

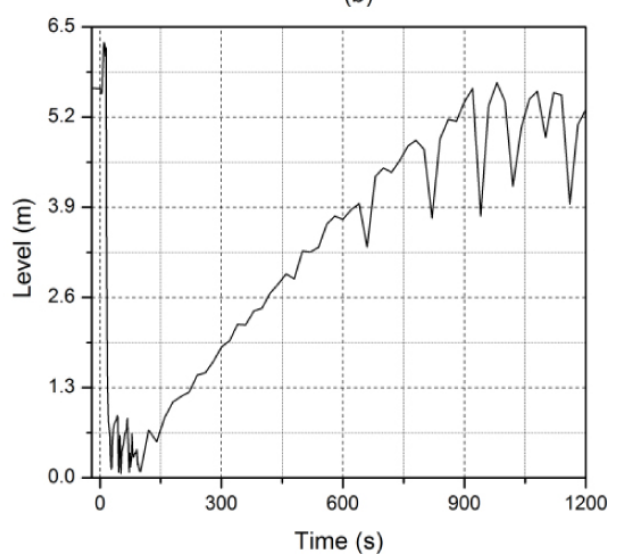

Fig. 7. Total reactor power (a). Steam generator 2 secondary side water level (b). 
(a)

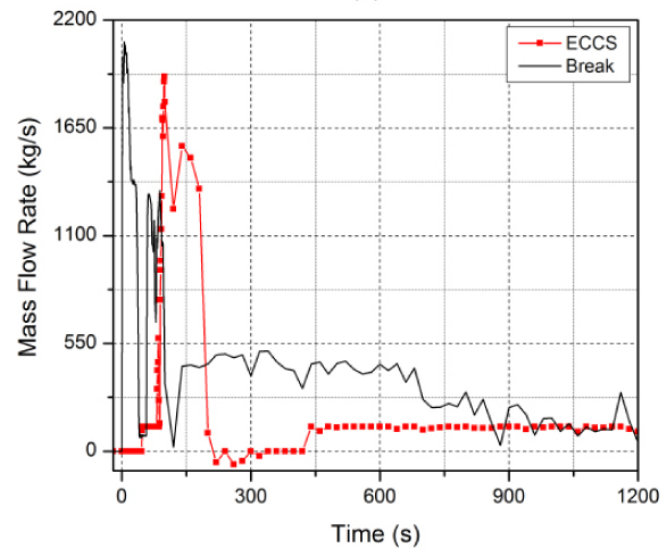

(b)

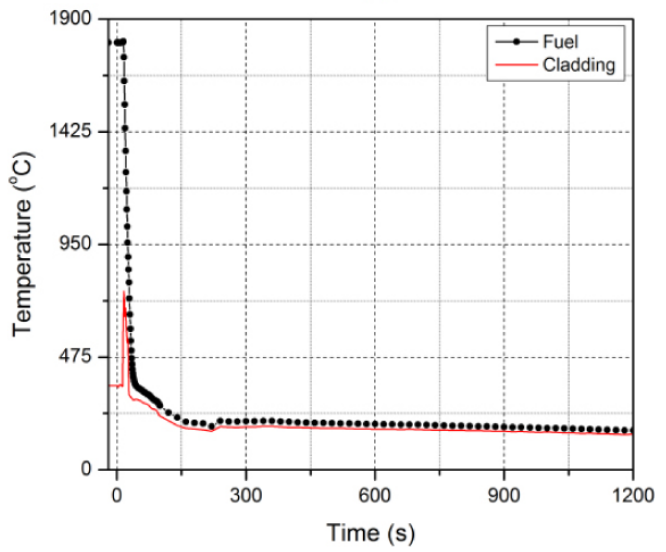

Fig. 8. Total mass flow rate injected and removed from RCS (a). Fuel and cladding temperature at level 18 of HS-605 (b).

protection system, this temperature increment does not reach values out of the allowed limits and, therefore, the reactor core integrity is guaranteed (see Fig. 8b).

\section{Conclusions}

A RELAP5-3D model of the Angra 2 PWR was developed using geometrical and material data from the final safety analysis report. Simulations of the reactor behavior during steady state and loss of coolant accident were performed. The analyzed parameters for the simulated cases demonstrated that the model with the control and protection system could successfully describe the reactor performance as in steady state as in transient operation conditions.

The analysis of the $200-\mathrm{cm}^{2}$ break between RCP and RPV demonstrates that the ECCS can provide sufficient cooling to prevent threat to the core. In the long term, the ECCS keeps the reactor coolant system filled and the decay heat is removed partly by the break flow. Taking the results of FSAR as a reference, the results obtained in this study show qualitatively similar behavior.

The next step of this work will be to insert others safety dispositive in the model and to observe how they can mitigate consequences after a severe transient. Moreover, the neutronic parameters will be inserted in the RELAP5-3D model, through the NESTLE code, to realistically reproduce $3 \mathrm{D}$ transient conditions with coupled thermal hydraulic/neutron kinetics effects.

The authors are grateful to CAPES, FAPEMIG and CNPq for the support. Thanks also to Idaho National Laboratory for the license to use the RELAP5-3D computer software.

\section{Nomenclature}

FSAR Final safety analysis report

NPP Nuclear power plant

LOCA Loss of coolant accident

SBLOCA Small break loss of coolant accident

$\begin{array}{ll}\text { RCP } & \text { Reactor coolant pump } \\ \text { RCS } & \text { Reactor coolant system } \\ \text { RPV } & \text { Reactor pressure vessel } \\ \text { TDV } & \text { Time-dependent volume } \\ \text { TDJ } & \text { Time-dependent junction } \\ \text { PRZ } & \text { Pressurizer } \\ \text { HS } & \text { Heat structure } \\ \text { ECCS } & \text { Emergency core cooling system } \\ \text { EFW } & \text { Emergency feedwater system } \\ \text { MFW } & \text { Main feedwater system }\end{array}$

\section{References}

1. THE RELAP5-3D ${ }^{\odot}$ CODE DEVELOPMENT TEAM, RELAP5-3D ${ }^{\odot}$ User's Manual (Idaho National Laboratory, Idaho Falls, 2009)

2. G. Sabundjian, D.A. Andrade, A. Belchior Jr. et al., The behavior of Angra 2 nuclear power plant core for a small break LOCA simulated with RELAP5 Code, AIP Conference Proceedings 1529, 151 (2013)

3. M.S. Rocha, G. Sabundjian, A. Belchior Jr. et al., Angra 2 Small Break LOCA Flow Regime Identification Through RELAP5 Code, in Proceedings of ENCIT 2012, 14th Brazilian Congress of Thermal Sciences and Engineering, Rio de Janeiro, Brazil (2012)

4. T. Crook, R. Vaghetto, A. Vanni, Y.A. Hassan, Sensitivity analysis of a PWR response during a loss of coolant accident under a hypothetical core blockage scenario using RELAP5-3D, in Proceedings of the 2014, 22nd International Conference on Nuclear Engineering, ICONE22, Prague, Czech Republic (2014)

5. Eletrobrás Eletronuclear, Final Safety Analysis Report Central Nuclear Almirante Álvaro Alberto - Unit 2, Eletrobrás Termonuclear S.A., Rev. 13 (2013)

6. K. Ivanov, A. Olson, E. Sartori, OECD/NRC BWR turbine trip transient benchmark as a basis for comprehensive qualification and studying best-estimate coupled codes, Nucl. Sci. Eng. 148, 195 (2004)

7. F. D'Auria, M. Frogheri, W. Giannoti, RELAP5/MOD3.2 Post Test Analysis and Accuracy Quantification of Lobi Test $B L-44$, International Agreement Report, NUREG/IA-0153 (1999) 
8. T. Bajs, D. Grgić, V. Sêgon, L. Oriani, L.E. Conway, Development of a RELAP5 Nodalization for IRIS Non-LOCA Transient Analyses, in Nuclear Mathematical and Computational Sciences: A Century in Review, A Century Anew (Gatlinburg, United States, 2003)
9. A. Petruzzi, F. D'Auria, Thermal hydraulic system codes in nuclear reactor safety and qualification procedures, Sci. Technol. Nucl. Install. 2008, 460795 (2008)

10. J.J. Duderstadt, L.J. Hamilton, Nuclear Reactor Analysis (John Wiley \& Sons Inc., 1976)

Cite this article as: Javier González-Mantecón, Antonella Lombardi Costa, Maria Auxiliadora Fortini Veloso, Claubia Pereira, Patrícia Amélia de Lima Reis, Adolfo R. Hamers, Maria Elizabeth Scari, Thermal hydraulic simulations of the Angra 2 PWR, EPJ Nuclear Sci. Technol. 1, 5 (2015) 